\title{
Biology and panpsychism: German evolutionists and a philosopher Theodor Ziehen (1862-1950)
}

\author{
G. S. Levit, U. Hossfeld
}

Friedrich-Schiller University, Jena,

Am Steiger 3, D-07743 Jena, Germany

For citation: Levit G. S., Hossfeld U. Biology and panpsychism: German evolutionists and a philosopher Theodor Ziehen (1862-1950). Vestnik of Saint Petersburg University. Philosophy and Conflict Studies, 2020, vol. 36, issue 2, pp. 240-253. https://doi.org/10.21638/spbu17.2020.203

Theodor Ziehen was a prominent German psychiatrist and psychologist and a marginal philosopher of the first half of the $20^{\text {th }}$ century who developed an exotic subjective-idealistic theory based on quasi-empirical psychological arguments. Although Ziehen was seen by contemporaries (most prominently by Vladimir Lenin) as a representative of the same philosophical current (empirio-criticism) as Mach and Avenarius, he never achieved their prominence in the history of philosophy. At the same time, Ziehen's philosophy became influential in German biology, first of all, due to his direct and very strong impact on Bernhard Rensch. Rensch, in his turn, was the most significant figure on the international scene of what is known as the Modern Evolutionary Synthesis in biology. Rensch was not the only biologist influenced by Ziehen's ideas. Ziehen had some communication with the "German Darwin" Ernst Haeckel and played a prominent role in the concept of the founder of biological systematics Willi Hennig. How to explain Ziehen's prominent place in the history of evolutionary biology, despite his obscurity in the history of philosophy? Our hypothesis is that Ziehen became a visible figure in evolutionary theory because of the monistic bias in German biology. Ziehen's epistemology appeared to be compatible with evolutionary monism and was developed by a practicing psychiatrist therefore obtaining a character of a quasi-experimental doctrine.

Keywords: Theodor Ziehen, Identism, empirio-criticism, Ernst Haeckel, Bernhard Rensch, Willi Hennig, psychomonism, monism, Modern Synthesis.

\section{Introduction}

The majority of biologists and historians of biology agree that there were three major historical forms of Darwinism [1-3]. Classical Darwinism is Darwin's own theory, which pushed forward the very idea of organic evolution and common descent while also introducing the principle of natural selection within the broad theoretical context. Classical Darwinism was followed by a split between neo-Darwinism and old-Darwinism: At the end of the $19^{\text {th }}$ century, Canadian-born English psychologist George John Romanes (1848-1894) recognized the crucial importance of the question "whether natural selection has been the sole, or but the main cause of organic evolution" [4, p. 1]. Answering this question, Romanes opposed Darwin, who admitted that natural selection has been assisted by the "subordinate principles", and Alfred Russel Wallace (1823-1913) along with August Weismann (1834-1914), maintaining that natural selection should be regarded as the only cause of evolution. To denote "the pure theory of natural selection to the exclusion of any supplementary theory" Romanes coined the term neo-Darwinism [4, p. 12]. Under 'sup-

(c) Санкт-Петербургский государственный университет, 2020 
plementary theories' Romanes understood 'Lamarckian factors' (use-inheritance) and the theory of sexual selection. The original Darwinian line of thinking preserving the priority of natural selection, but combining both Lamarckian and selectionist factors along with moderate orthogenesis and some mutationism, was continued by the "old-Darwinian" school represented, first of all, by the "German Darwin" Ernst Haeckel (1834-1919) and his successor at Jena University Ludwig Plate (1862-1937).

Finally, the Synthetic Theory of Evolution (STE) or the Modern Synthesis originated in the early 1930s, after a period of an "eclipse" of Darwinism [5] and the associated dominance of alternative (non-Darwinian) theories of evolution. According to Ernst Mayr (1904-2005), the Synthesis was completed in 1947 and the so-called period of 'postsynthesis' began $[6$, p. 20]. The STE proposed a logically coherent and empirically wellsubstantiated theoretical system, which incorporated several branches of biology such as classical genetics, population genetics, systematics, evolutionary morphology, developmental biology, palaeontology, etc. Within the STE, "non-selectionist factors of evolution, especially isolation, chance events, and population size are emphasized. Selection is regarded as important, but only as one of several evolutionary factors" [1, p. 44]. With all these factors taken into account, the STE succeeded in proposing a convincing theory of macroevolution.

In Germany, two major figures in the growth of evolutionary theory were Ernst Haeckel and Berhard Rensch (1900-1990). Ernst Haeckel was a younger contemporary of Darwin and one of his most influential proponents on the continent. Haeckel belongs to an old-Darwinian current, i.e. his goal was to exactly follow Darwin in his description of evolutionary mechanisms. Rensch was, arguably, the most influential figure on the international scene of what is known as the Modern Synthesis in Germany [7]. Simply put, Haeckel and Rensch were the two most important advocates of Darwinism in German lands in both "classical" and "synthetical" periods of the growth of evolutionary biology. Yet, it is astonishing that both of them were under the influence of a relatively little-known German philosopher and psychologist Theodor Ziehen (1862-1950). Especially Rensch owed his whole philosophical worldview to Ziehen. Ziehen also significantly influenced the "father" of phylogenetic systematics Willi Hennig (1913-1976), being one of his major philosophical inspirations along with Ludwig von Bertalanffy (1901-1972) [8]. At the same time, Ziehen remains marginal in the history of philosophy. For example, the inclusive Stanford Encyclopedia of Philosophy provides only three references to Ziehen in the context of discussing logics and psychology, but without mentioning his major philosophical publications ${ }^{1}$.

Our objective here is to describe Ziehen's philosophical views and to explain why he became so influential in the history of German evolutionary biology, while remaining almost fully ignored by the standard histories of philosophy.

\section{Theodor Ziehen's life path}

It is difficult to attribute Ziehen to a certain scientific discipline. He was a psychologist, neurologist, psychiatrist, and philosopher who enjoyed great fame during his life time, but subsequently was almost completely neglected by the history of science and

\footnotetext{
${ }^{1}$ https://plato.stanford.edu/search/searcher.py?query=Ziehen (accessed: January 21, 2019).
} 


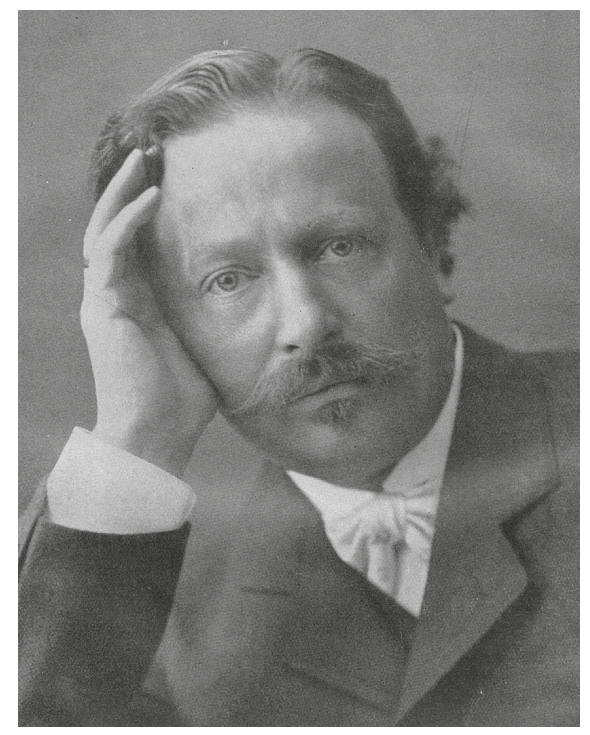
[10])

Fig. 1. Portrait of Theodor Ziehen (from:

philosophy: "Theodor Ziehen belongs among the great universal thinkers of the end of the nineteenth century and the twentieth century. Unfortunately, his accomplishments have largely been forgotten, although contemporaries compared him to Einstein and Leibniz" [9, p. 1369].

Ziehen was born on 12 November 1862 in Frankfurt am Main as the son of a Protestant theologian, philologist, and writer Eduard Ziehen (1819-1884) [10, p.211]. His brother Ludwig Ziehen (1871-1944) is known as a pedagogue and historian. Ziehen attended a so called "humanist high school" (humanistisches Gymnasium), where he became proficient in classical languages (Greek and Latin) and showed a philosophical interest especially to the philosophy of Plato, Immanuel Kant, Arthur Schopenhauer, and Indian philosophy. Ziehen himself wrote about this period of his life: "Already at that time I decided that philosophy is the ultimate objective of my life" [10, p. 220].

Despite his love for philosophy, he decided to study medicine because it was the only way to receive a stipend, which he urgently needed. In 1881, he enrolled in the Würzburg university where attended classes in the history of philosophy by Georg Neudecker (born in 1850) who, in his turn, was significantly influenced by Fichte. Following Neudecker's advice, Ziehen studied modern philosophers, paying special attention to Spinoza, David Hume, Hegel, and George Berkeley. From the side of the natural sciences, he was deeply impressed by the famous botanist Julius Sachs (1832-1897) [10, p.221]. Two years later (1883) he moved to Berlin to continue his medical education and received his doctorate in 1885 with the $\mathrm{PhD}$ thesis Über die Krämpfe infolge elektrischer Reizung der Großhirnrinde (On the Spasms of Cerebral Cortex as a Consequence of Electrical Stimulation). His decision to specialize in psychiatry was connected with its close connections to psychology and philosophy. Besides medicine and philosophy, Ziehen studied mathematics and theoretical physics.

In 1885 he began to work as an assistant volunteer at the famous mental hospital in Görlitz under the guidance of Karl Ludwig Kahlbaum (1828-1899) and in 1886 he moved to Jena to become a "senior doctor" (Oberarzt) in Otto Binswanger's (1852-1929) psychiatric clinic [11, p. 422]. Ziehen remained in Jena for 14 years. At that time, Jena was one of the major places in the history of Darwinism due to the activities of Ernst Haeckel. In Jena, Ziehen also came into contact with Friedrich Nietzsche (1844-1900), who was one of his patients. In 1887 Ziehen completed his Habilitation (Dr. Sc. thesis) with the topic Sphygmographische Untersuchungen an Geisteskranken (Sphygmographic Studies on Mentally Ill Patients) and became a "Privatdozent" for psychiatry [11, p.423].

In 1892, Ziehen became an extraordinary professor in Jena, but in 1896 he left the clinic and opened a private neurological practice [11, p. 424].

In 1900 he got a call for a professorship of psychiatry in Utrecht, and three years later (1903) he took up the Chair in Psychiatry at Halle. After only a half a year in Halle, Zie- 


\section{DIE GRUNDLAGEN DER PSYCHOLOGIE}

VON

THEODOR ZIEHEN

I. $\mathrm{BUCH}$

ERKENNTNISTHEORETISCHE

GRUNDLEGUNG DER PSYCHOLOGIE

\section{宅}

LEIPZIG UND BERLIN

DRUCK UND VERLAG VON B. G. TEUBNER

I 9 I 5

Fig. 2. Title page of Ziehen's book “Die Grundlagen der Psychologie" (1915)

hen moved to Berlin to become the Director of the Clinic for Psychiatry and Neurology at the famous Charité Hospital, a post he maintained until his retirement in 1912, during which he received in 1910 a doctorate (honoris causa) from the Philosophical Faculty at Berlin University for his important contributions to philosophy [11, p. 425]. In 1912 he moved with his family to a small villa in Wiesbaden, where he spent a few years devoted to psychology and philosophy. During the First World War Ziehen helped establish the Flemish University in Ghent, but in 1917 came back to Halle as a professor of philosophy, co-director of philosophical seminars, and a keeper of a psychophysical collection. In that period, he divided his time between philosophy, child psychology, and pedagogy. In 1923 he became a Dean of the Philosophical Faculty and in 1927, Rector in Halle [11, p. 425]. In 1930 he retired and moved to Wiesbaden, where he died on 29 December 1950. He avoided membership in the Nazi Party and never supported national socialism [11, p. 426], which was unusual among German physicians. $45 \%$ of German physicians belonged to the Nazi party, about 7 times the mean rate for the employed male population of Germany [12].

Ziehen's entire oeuvre amounts to more than 400 works on various subjects including two dozen monographs. A significant part of his later works is devoted to philosophy. 


\section{Ziehen's philosophy}

Ziehen developed a philosophical theory proceeding from psychological "observations" and closely related to psychology, medicine, and natural sciences in general. His philosophy was thought to be a foundation of psychology. For example, the first volume of his Die Grundlagen der Psychologie (Foundations of Psychology) had the subtitle Erkenntnistheoretische Grundlagen der Psychologie (The Epistemological Foundations of Psychology) and was completely devoted to his theory of knowledge and cognition [13].

His objective was to establish an epistemology "free of speculations" but based on the analysis of facts. Along the lines of the philosophies of Ernst Mach and Richard Avenarius, Ziehen developed his own philosophical approach that was marked by realism and objectivism. His idealistic cognitive theory, which directly opposed the growing influence of materialism in the natural sciences, led to massive attacks by Marxists, including Vladimir Lenin (1970-1924) [9]. Indeed, both Ernst Mach (1838-1916) and Vladimir Lenin cited Ziehen. Mach seemed to hold mixed opinions about Ziehen. For example, in the introduction to the Russian edition of his "Analysis of sensations" first published in 1908, and later mentioned by Lenin, Mach wrote that at the end of the 1880s that after he had come into contact with the works of Avenarius (1843-1996), Wilhelm Schuppe (1836-1913) and Ziehen, he came to the conclusion that they were following very close - if not the same - paths [14, p. 43]. Yet, in a private letter to the Austrian philosopher Wilhelm Jerusalem (1854-1923) on July 1, 1915, Mach was rather skeptical about Ziehen's philosophical achievements: "I have partly read Ziehen ${ }^{2}$ and am of your opinion about him. For the branding together of Plato and Goethe, if I may be allowed to give an opinion, strikes me as rather comical" [15, p. 225]. As we will later see, it is exactly this synthesis of Plato and Goethe that made Ziehen popular among German evolutionists. In fact, Lenin criticized Ziehen as a "psychomonist" and one of the followers of Mach and Avenarius in his famous Materialism and Empirio-criticism [16].

Indeed, psychomonism seems to be a suitable characteristic of Ziehen's philosophy, although Ziehen himself strictly declined this term [17, p. 15] rendering his relationship to positivism more complex: although he was seen as a follower of Mach and Avenarius, the fact is that Ziehen developed his epistemology independently, having completed the first version of the Psychophysiologische Erkenntnistheorie (Psychophysiological Epistemology) in 1898 prior to reading Mach, Avenarius, and Schuppe [10].

In the $2^{\text {nd }}$ edition of Psychophysiologische Erkenntnistheorie Ziehen summarized his theory of knowledge [18]. He begins with the "given" (later he invents the notion "Gignomene", see [17, p.2]), with sensations and perceptions: "Everything that is given is either sensation or perception. Initially, we get sensations; then they are followed by recollections and perceptions" $[18, \mathrm{p} .4]$. This, according to Ziehen, is consistent with empirical psychology. All things are only perceptions. Simple perceptions lay a foundation for complex perceptions having no direct analogies in sensations. For example, a complex perception "the plant" does not refer to any particular plant. The actual objective of empirical psychology is the study of complex perceptions $[18$, p. 6]. The complex perceptions "Myself" and "Thing" make sense only as perceptions having no independent "reality". To support his view, Ziehen appeals to Berkeley's claim: "The external objects subsist not by themselves, but exist in our minds" [18, p.7]. The perception of causality is a perception

${ }^{2}$ With all probability he read Ziehen's Die Grundlagen der Psychologie (1915). 
of relationships. A certain repeatedly occurring order of sensations amounts to the idea of causality. The perception of relationships plays a crucial role in natural sciences, which operate with such perceptions as identity (sameness), affinity, distinctness, change, causality, and others. For example, the first three relationships (sameness, affinity, distinctness) lay the foundation for systematic categories in biology (individual, species, genus, etc.) [18, p. 17]. Along these lines arrives Ziehen at what he calls "the law of causality" (Kausalgesetz): 1. Similar succession of sensations will be often repeated; 2 . The succession of sensations remains the same when substituted by perceptions. The "causal lawfulness" will be distinguished from a "parallel lawfulness", something we would call a subjective perception of things. Ziehen illustrates this idea of causal and parallel lawfulness with two examples [10, p.227]. The fall of a stone causes a cascade of physiological reactions including the activation of the cerebral cortex. It is repeatable and independent of individual sensations. This is an example of a causally lawful process. A perception of a "blue sky" illustrates a parallel lawfulness, because there is no "blue" out there and the sky may appear as blue or red, depending on many factors.

All perceptions may undergo a process of "reduction". As we have already mentioned, Ziehen distinguished between sensations and perceptions. Simple perceptions are simple recollections of sensations. These recollections, however, will be combined and re-combined once again until they build up a coherent picture of sensations. Such perceptions, providing a coherent picture of the world out there, are the result of the process of "reduction" $[18, \mathrm{p} .40]$. The "reduction" is possible due to the "law of causality" mentioned above. Sometimes Ziehen used the term "reductions" and "causal components" interchangeably $[18$, p.44]. There are three types of reduction, according to Ziehen. The reduction of the external objects, the reduction of the self, and the reductions of other "selfs" (other subjects). Ziehen is against solipsism, because "self" is not something primarily given. "Self" is the result of both reduction as well as of external objects. Kant, according to Ziehen, approached the same issue when introducing his famous notion of the "thing-in-itself". Yet, Ziehen emphasizes that current researchers have a privilege to be able to investigate this problem by means of experimental psychology and physiology. These new branches of science support the view that neither primary sensations nor the outcomes of reduction are autonomous. But they are also not rigidly connected to each other. There are laws regulating relationships between various reduction processes. All sensations and perceptions undergo reduction. Ultimately, "any religion is more or less a complex system of reduced perceptions" [18, p. 94]. The same is true for any scientific hypothesis or any philosophical system including Ziehen's very own epistemology. To the objection that objective laws of nature would disappear in this purely psychic universe, Ziehen answered that the laws of physics will persist, but they will be seen as describing relations between reduced sensations (perceptions) and not between material bodies out there [18, p. 108].

Ziehen's epistemology is tightly connected to what can be called his ontology. In the Grundlagen der Psychologie, Ziehen introduced "the principle of immanence" [13, p. 11]. It embraced three logically interconnected claims: 1 . It is impossible to establish a meaningful concept of type [Gattung] covering all the given [Gignomene]; 2. It is impossible to distinguish Gignomene from non-Gignomene; 3 . It is impossible to imagine something that would be totally different from Gignomene. In other words, the "immanent philosophy" is beyond the opposition between "physical" and "psychical". The "immanent philosophy" rejects both "metaphysical" and "metapsychical" [13, p.12]. 
Of primary importance to our discussion here is that the "principle of immanence" builds a direct bridge between Ziehen's epistemology and his monism: "It is evident that the immanence principle, in a certain sense, establishes monism" [13, p. 14]. For Ziehen, this was especially true of the third claim of the principle, because it excludes the existence of something essentially different from the "given". A real transcendence is impossible. All "transcendences" found in the history of philosophy are just "words".

The mature version of both Ziehen's epistemology and ontology can be found in two volumes of the second edition of his Erkenntnistheorie (Theory of Knowledge) [17; 19]. The first volume has the subtitle Allgemeine Grundlegung der Erkenntnistheorie. Spezielle Erkenntnistheorie der Empfindungstatsachen einschließlich Raumtheorie [General Foundation of Epistemology. Special Epistemology of Sensations Including the Theory of Space]. The second part published in 1939 is devoted to Zeittheorie. Wirklichkeitsproblem. Erkenntnistheorie der anorganischen Natur (erkenntnistheoretische Grundlagen der Physik). Kausalität [Theory of Time. The Problem of Reality. Epistemology of the Inorganic Nature (Epistemological Foundations of Physics). Causality].

Here Ziehen even more explicitly expressed his monist ontology. Both his epistemology and his monism became crucial for the growth of German evolutionary biology.

\section{Bernhard Rensch Ziehen's influence}

Bernhard Rensch was of the best known "architects" of the Evolutionary Synthesis, who crucially contributed to the growth of Darwinism in Germany and worldwide. At the same time, Rensch created an exotic and sophisticated evolutionary metaphysics, which became an integrated part of his universal evolutionism.

In 1947 Rensch published his most important "synthetic" book Neuere Probleme der Abstammungslehre: Die Transspezifische Evolution [20]. The book, which became known in English-speaking countries under the title Evolution above the Species Level, was written in Prague during the Second World War. The draft of the contents of the book found in the Archives of the Academy of Sciences in Prague shows that Rensch conceived his work from the very beginning as a deep theoretical investigation with explicit methodological reflections [21]. It is not a coincidence that already in the first edition of the book, Rensch cited Theodor Ziehen, his main philosophical inspiration. In this book Ziehen is mentioned more often than Darwin. From the viewpoint of evolutionary theory, the objective of the book was to substantiate the Darwinian theory of macroevolution. Rensch's novel was also the line of argumentation developed as a contribution to epistemology, philosophy of science, and metaphysics, and written under the influence Ziehen. In subsequent books, Rensch developed this initial concept into a full-blown philosophical system, which laid the foundation for his evolutionary views.

In one of his last works, Probleme genereller Determiniertheit allen Geschehens (The Problems of the General Determinacy of all Occurrences), Rensch presented his pantheistic metaphysics as a holistic and scientifically based worldview [22, p. 11]. Rensch constructs his philosophy proceeding from the general epistemological assumption that "the only entirely reliable foundation for a philosophical worldview is the indisputable reality [Wirklichkeit] of the phenomena [Tatsachen] of consciousness" [22, p. 11]. This sounds like a repetition of Ziehen's "immanence principle", but Rensch goes further and provides his epistemology with an evolutionary explanation. The very human ability to analyze is 
an inherited feature acquired in the course of evolution. The most essential trait of human ability to "draw conclusions" can be explained by the adaptedness of the human mental apparatus to the regularities of the external world. This adaptedness to the lawfulness of the "extra-mental" reality is the premise of the correlation between the mental and extramental worlds. Rensch makes Ziehen's philosophy less exotic by claiming that there is, indeed, only one single reality, but it has two fundamentally different aspects: the mental and the material.

The basis of Rensch's philosophy includes the negation of acausal processes. In his view, both the inorganic and the organic worlds are causally determined [22, p. 15-16]. Thus natural selection is the major factor determining organismic evolution. Biological progress can be fully explained in terms of Darwinian selectionism. For Rensch, biological evolution is a determined and gradual process, although it involves stochastic events, such as random mutations.

The evolution of human cultures proceeds mostly on the level of non-heritable characters, Rensch continues, and it is important to distinguish between psychic and neurophysiological phenomena. Rensch refers to Karl Popper's concept of the relationships between psychic and neurophysiologic levels as an example of dualism. Popper assumed that there are two principally different essences [Seinswesen]: the psychic phenomena, on the one hand, and the neurophysiological on the other. Rensch formulates his own position by contrasting it to Popper's dualism. If purely psychic phenomena, as for example volition, could influence muscle contractions, Rensch argues, it would violate the law of energy conservation making the purely biochemical explanation of muscle contractions impossible [22, p. 34].

Another possibility would be to assume that mental [geistige] processes run in parallel to events in a material world. Rensch labels this position psychological parallelism. Yet, psychological parallelism cannot explain why the physiologically identical brain processes can cause various mental effects.

Following Ziehen, Rensch argued, that for a human being the only indisputable objects are his own psychic phenomena resulting from immediate experiences: perceptions, imaginations, feelings, and thoughts. Only an analysis of these experiences makes it possible to develop concepts of an extra-mental world, which appears as a visible and testable reality. Matter appears as "the ultimate something", which will perhaps in the future be described only in terms of interactions of various forces, causal chains, and fundamental constants. Rensch appealed to Ziehen's psycho-physiological epistemology to introduce a "monistic principle" [22, p. 29]. As any kind of philosophical monism, the "monistic principle" constitutes an ultimate, ontologically definable, reality, which cannot be multiplied or decomposed into further elements. Rensch argued that the reduction of the elementary mental features (sensations and perceptions) to their foundations will inevitably lead to the concept of "the ultimate something" that underlies the world and cannot be decomposed to further elements [22, p. 35]. One could appeal to Spinoza's concept of substance in order to avoid dualism and to give the name to this "ultimate something", Rensch argued.

Along these lines, Rensch arrived at his concept of psychophysical identism [22, p. 36]. Rensch presented this concept for the first time in the Abstammungslehre [20], although at that time he employed another term (with the same meaning) hylopsychism, also borrowed from Ziehen [19, p. 113]. Quite in accord with Ziehen, Rensch claimed: "We would 
like to point out here once more that this worldview is an idealistic one, since what is primarily given to us is the 'psychic'; there is definitely no opposition between subject and object, matter and soul; even the abstract reductionist world [Reduktwelt] of natural scientists should not be searched for outside of the 'conscious' [Bewußten]" [20, p. 372].

In the Biophilosophie [23; 24], Rensch converted Ziehen's idealism into the so called "identistic" foundation of his philosophy of biology and coined the term "panpsychisticidentical or polynomistic world view". Rensch formulated two basic "facts" constituting the basis of panpsychistic identism: " 1 . The only reality of which we can be absolutely certain relates to experienced phenomena, which include sensations, mental images, feelings, and volitional processes as a whole. 2. Man does not consist of two separate components - matter and mind, or body and soul, but represents an indivisible psychophysical unity" [24, p. 299].

Rensch's panpsychism lead to conclusions crucial for evolutionary biology. First of all, it was the hypothesis of psycho-phylogeny proving that all psychic abilities develop gradually in the course of phylogeny. Even protists react to impulses in a way similar to that of organisms with a nervous system. But if we admit that the psychic abilities developed during the entire course of phylogeny as a continuous process, why should we ascribe "the Psychic" only to the first stages of biological evolution without looking for its roots in the geological and astronomic pre-history of evolution? Rensch claims that we can trace this down to the level of proto-phenomena preceding any kind of material evolution (both abiotic and biological) and underlying the phenomenological nature of the material world: "the proto-phenomena precede even the inanimate pre-stages of phenomena, and respectively matter is of a proto-phenomenal nature" [24, p. 406]. In other words, the protopsychic properties are immanent to matter. Nihil est in intellectu, quod non fuerit in sensu can therefore be substantiated also phylogenetically, Rensch concludes. In other words, Rensch's identism is a kind of monism, which was inspired by Ziehen.

Rensch was the most important, but not the only German evolutionary scientist who was under Ziehen's influence. We must also consider Ernst Haeckel, certainly the most prominent champion of early Darwinism in Germany [25].

Quite soon after the publication of Darwin's seminal On the Origin of Species [26], Haeckel began serious research along these Darwinian lines. It is now 150 year ago that Haeckel published his first major scientific work, Generelle Morphologie der Organismen, in 1866 [27]. Here for the first time he started to formulate his famous biogenetic law, claiming that ontogeny recapitulates phylogeny. The popularisation of Haeckel's ideas followed in 1868 when a collection of lectures that he had held at Jena University (where he was the first professor of zoology) were published as Natural History of Creation [28]. This popular science book became a bestseller and was also translated into many different languages. Thereafter, Haeckel published several books popularising Darwinian theory and the philosophy of monism, which he passionately supported. Ziehen belongs to the younger generation of monism champions; he was four years old when Haeckel had already published his monumental pro-Darwinian theory, so one cannot claim that he shaped Haeckel's views. However, Ziehen exchanged correspondence with Haeckel, and devoted a voluminous paper to the analysis of Haeckel's monism [29]. Ziehen was critical towards Haeckel's monism, because Haeckel, in his view, failed to elaborate a sound epistemology. Ziehen praised Haeckel for the "monistic principle", but claimed that Haeckel never created a philosophical system substantiating this principle, restricting himself to 


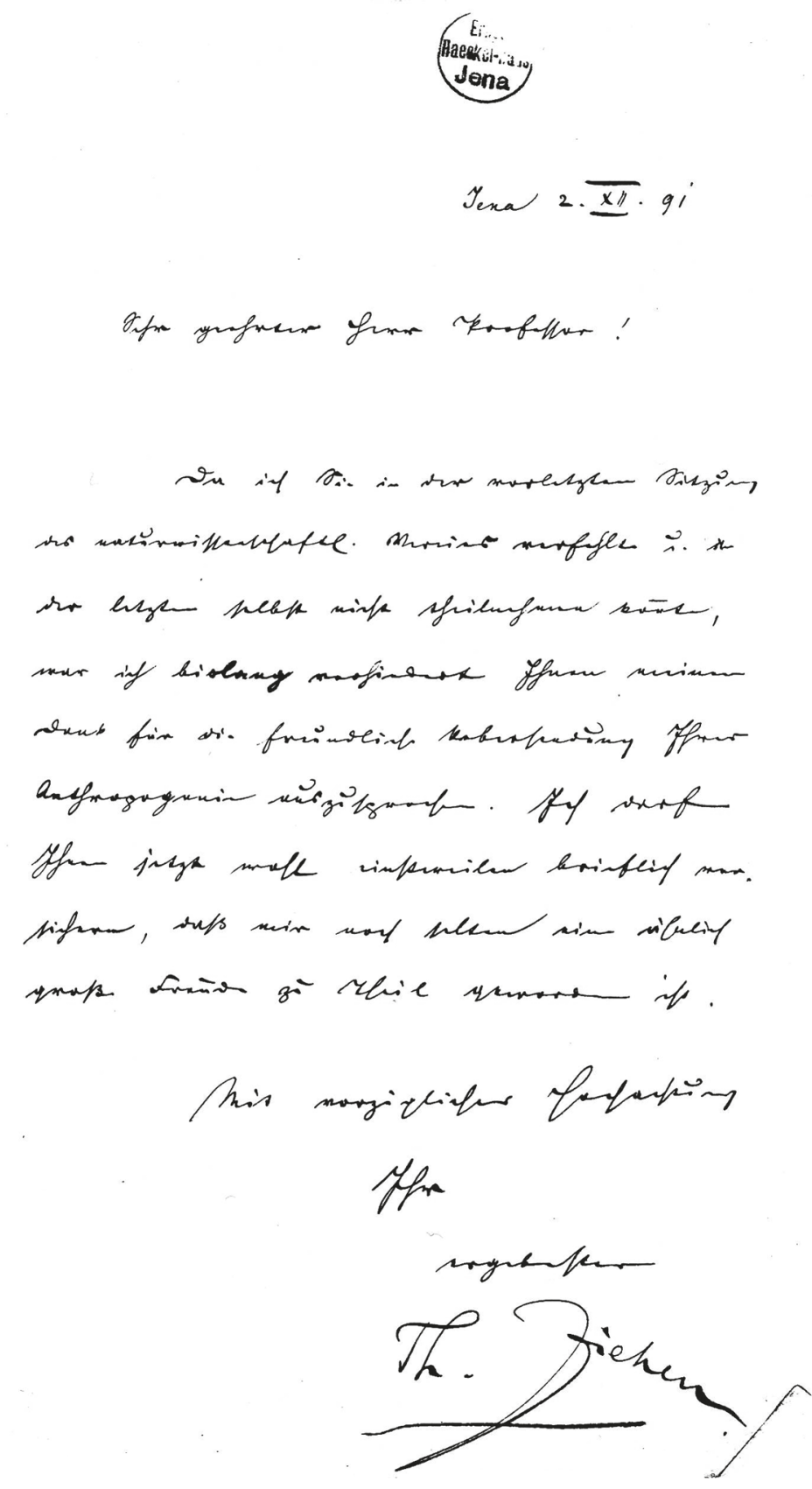

Fig. 3. Theodor Ziehen was in personal communication both with Haeckel and Rensch. Here Ziehen's letter (02.12.1891) to Haeckel (from the ErnstHaeckel-Hause Archive in Jena). In this letter Ziehen thanks Haeckel for sending him a copy of Anthropogenie 
a declarative mode. Haeckel, in his turn, listed Ziehen's Leitfaden der physiologischen Psychologie (Guidelines of physiological psychology, [30]) as recommended reading in his Anthropogenie [31].

In addition, it should be mentioned that Ziehen was one of the major philosophical inspirations for the founder of phylogenetic systematics, Willi Hennig. Phylogenetic systematics is a field of biology reconstructing the ways that have led to the current biodiversity. As the name suggests, phylogenetic systematics is based on the concept of phylogeny as coined by Ernst Haeckel. Hennig elaborated a philosophy underlying his systematics that was based on Ziehen, Rudolf Carnap (1891-1970) and Ludwig Bertalanffy [32]. Hennig, among others, was fascinated by Ziehen's idea species, and higher taxa; indeed, for him all life on Earth are to be considered individuals of increasing complexity. But most crucial for Hennig was Ziehen's monistic ontology: "For Ziehen, prodigiously cited by Hennig, the material causes of our sensory perceptions accordingly are not objects, but centers of increased density in a global field of energy. On that account, a qualitative difference between matter and energy disappears $<\ldots>$ " [33].

\section{Conclusions}

Theodor Ziehen was a marginal German philosopher of the first half of the $20^{\text {th }}$ century who developed an exotic subjective-idealistic theory based on quasi-experimental psychological methods. Although Ziehen was seen by contemporaries (most prominently by Vladimir Lenin) as a representative of the same current as Mach and Avenarius, he never achieved their prominence in the histories of philosophy. For example, The $O x$ ford Companion to Philosophy mentions both Mach and Avenarius, but completely neglects Ziehen [34]. The same is true for German-language textbooks and encyclopedias. The Dictionary Philosophie und Naturwissenschaften (Philosophy and Natural Sciences), specifically aimed to elucidate the connection between science and philosophy, does not mention Ziehen at all [35]. How to explain Ziehen's prominent place in the history of evolutionary biology, despite his obscurity in the history of philosophy?

Our hypothesis is that Ziehen became a visible figure in evolutionary theory because German biology was strongly influenced by the philosophy of monism. Monism was a characteristic feature of German tradition in evolutionary biology and was not as prominently presented in English-speaking or Russian speaking countries [36]. Both of the most important figures of the first and the second Darwinian revolutions in Germany were explicit monists. Haeckel's successor in Jena Ludwig Plate was an explicit monist as well, although he developed his own "philosophy".

In Haeckel's view, evolution is a universal phenomenon affecting everything from inorganic matter to man. He believed in the unity of body and soul, and the unity of spirit and matter. This monism guided all of Haeckel's major works, beginning with the Generelle Morphologie [37]. Monism and evolutionary theory were for Haeckel parts of the same research program labelled the "monistic doctrine of evolution" (monistische Entwicklungslehre), and ultimately were aimed at unifying science and religion on a biological foundation [38, p. 66]. Rensch, being a major German "co-architect" of the Modern Synthesis, developed his version of synthetic Darwinism into an all-embracing metaphysical conception based on a kind of Spinozism situated within the same tradition as Haeckel's monism. Henning did not escape the monist temptation either. Looking for the separation of 
subjective from objective components of perception in the pursuit of systematics, Hennig recognised Ziehen's monism as a philosophy that would allow that distinction [32]. Besides, Ziehen's monist epistemology was attractive to biologists because it looked like a fundamental philosophy originating from an experimental science. Ziehen was at home among evolutionists who were looking for a philosophically deep methodology developed by "somebody like us". In this way, the exotic psychologist Theodor Ziehen became a philosophical inspiration for Bernhard Rensch and other German evolutionists, while disappearing from the history of philosophy [38].

\section{Acknowledgements}

We are very thankful to Dr. Ian G. Stewart (Halifax, Canada) for many valuable suggestions. Our special thanks are extended to Dr. Thomas Bach (Ernst-Haeckel-Haus, Jena) for providing us with archival materials.

\section{References}

1. Reif, W.-E., Junker, T. and Hossfeld, U. (2000), The synthetic theory of evolution: general problems and the German contribution to the synthesis, Theory in Biosciences, no. 119, pp. 41-91.

2. Kutschera, U. and Niklas, K. J. (2004), The modern theory of biological evolution: an expanded synthesis, Naturwissenschaften, no. 91, pp. 255-276.

3. Levit, G. S. and Hossfeld, U. (2011), Darwin without borders? Looking at "generalised Darwinism" through the prism of the "hourglass model", Theory in Biosciences, no. 130, pp. 299-312.

4. Romanes, G. J. (1895), Darwin and After Darwin: Post-Darwinian questions: Heredity and utility, Chicago: Open Court.

5. Bowler, P. J. (1992), The eclipse of Darwinism, Baltimore and London: The John Hopkins University Press.

6. Mayr, E. (1999), Thoughts on the evolutionary synthesis in Germany, in Junker, T. and Engels, E.-M., Die Entstehung der Synthetischen Theorie: Beiträge zur Geschichte der Evolutionsbiologie in Deutschland, Berlin: Verlag für Wissenschaft und Bildung, pp. 19-29.

7. Hossfeld, U. and Levit, G. S. (2012), Bernhard Rensch — biologischer Universalist im 20. Jahrhundert, in Biologie in unserer Zeit, vol. 4, no. 42, pp. 3-4.

8. Rieppel, O. (2016), Willi Hennig as a Philosopher, in Williams, D., Schmitt, M. and Wheeler, Q. (eds), The Future of Phylogenetic Systematics: The Legacy of Willi Hennig, Cambridge: Cambridge University Press, pp. 356-376.

9. Gerhard, U.-J. and Blanz, B. (2004), Theodor Ziehen, American Journal of Psychiatry. vol. 161, no. 8, p. 1369.

10. Ziehen, T. (1923), Beitrag, in Schmidt, R. (ed.), Die Philosophie der Gegenwart in Selbstdarstellungen, vol. 4., Leipzig: Meiner Verlag, pp. 219-236.

11. Castell, R. (2003), et al. Geschichte der Kinder- und Jugendpsychiatrie in Deutschland in den Jahren 1937 bis 1961, Göttingen: Vandehoek \& Ruprecht Verlag.

12. Seeman, M. V. (2005), Psychiatry in the Nazi Era, Can J Psychiatry, no. 50, pp. 218-225.

13. Ziehen, T. (1915), Die Grundlagen der Psychologie, I. Buch, Erkenntnistheoretische Grundlegung der Psychologie Verlag, Leipzig und Berlin Verlag von B. G. Teubner.

14. Mach, E. (2005), Analysis of Sensations, Moscow: Territoriia budushchego Publ. (In Russian).

15. Blackmore, J., Itagaki, R. and Tanaka, S. (eds) (2001), Ernst Mach's Vienna 1895-1930 (Boston Studies in the Philosophy of Science 218), Dordrecht: Kluwer Academic Publishers.

16. Lenin, V. (1972), Materialism and Empirio-criticism: Critical Comments on a Reactionary Philosophy, in Lenin, V., Collected Works, vol. 14, Moscow: Progress Publ., pp. 17-362. Available at: https://www. marxists.org/archive/lenin/works/1908/mec/four4.htm (accessed: 21.01.2019).

17. Ziehen, T. (1934), Erkenntnistheorie. Teil I, Jena: Gustav Fischer Verlag.

18. Ziehen, T. (1907), Psychophysiologsische Erkenntnistheorie, Jena: Zweite Auflage, Gustav Fischer Publ.

19. Ziehen, T. (1939), Erkenntnistheorie. Teil II, Jena: Gustav Fischer Verlag. 
20. Rensch, B. (1947), Neuere Probleme der Abstammungslehre. Die transspezifische Evolution, Stuttgart: Gustav Fischer Verlag.

21. Hopwood, N. (2015), Haeckel's Embryos: Images, Evolution, and Fraud, London: University of Chicago Press.

22. Rensch, B. (1988), Probleme genereller Determiniertheit allen Geschehens, Berlin and Hamburg: Parey Publ.

23. Rensch, B. (1968), Biophilosophie auf erkenntnistheoretischer Grundlage (Panpsychistischer Identismus), Stuttgart: Gustav Fischer Verlag.

24. Rensch, B. (1971), Biophilosophy, New York: Columbia University Press.

25. Hoßfeld, U. and Olsson, L (2003), The road from Haeckel. The Jena tradition in evolutionary morphology and the origin of „Evo-Devo“, Biology \& Philosophy, vol. 18, no. 2, pp. 285-307.

26. Darwin, Ch. (1859), On the Origin of Species, London: John Murray.

27. Haeckel, E. (1866), Generelle Morphologie der Organismen, 2 Bde. I. Bd. Allgemeine Anatomie der Organismen. II. Bd.: Allgemeine Entwickelungsgeschichte der Organismen, Berlin: Verlag von Georg Reimer.

28. Haeckel, E. (1868), Natürliche Schöpfungsgeschichte, Berlin: Georg Weimar Verlag.

29. Ziehen, T. (1919), Haeckel als Philosoph, Die Naturwissenschaften, vol. 7, no. 50. pp. 958-961.

30. Ziehen, T. (1891), Leitfaden der physiologischen Psychologie in 14 Vorlesungen, Jena: Gustav Fischer Verlag.

31. Haeckel, E. (1910), Anthropogenie oder Entwicklungsgeschichte des Menschen: Zweiter Teil, Leipzig: Wilhelm Engelmann Verlag.

32. Rieppel, O. (2007), The metaphysics of Hennig's, phylogenetic systematics: substance, events and laws of nature, Systematics and Biodiversity, vol. 5, no. 4, pp. 345-360.

33. Rieppel, O. (2006), On concept formation in systematics, Cladistics, no. 22, pp. 474-492. Press.

34. Honderich, T. (ed.) (2005), The Oxford Companion to Philosophy, $2^{\text {nd }}$ ed., Oxford: Oxford University

35. Hörz, H., Liebscher, H., Löther, R., Schmutzer, E. and Wollgast, S. (eds.) (1997), Philosophie und Naturwissenschaften, Bonn: Pahl-Rugenstein.

36. Levit, G.S. and Hossfeld, U. (2017), Major Research Traditions in Twentieth-Century Evolutionary Biology: The Relations of Germany's Darwinism with Them, in Delisle, R. (ed.), The Darwinian Tradition in Context, Cham, Springer Nature, pp. 169-193.

37. Hossfeld, U. (2010), Absolute Ernst Haeckel, Freiburg i.B.: Orange Press.

38. Levit, G. S., Simunek, M. and Hossfeld, U. (2008), Psychoontogeny and Psychophylogeny: The Selectionist Turn of Bernhard Rensch (1900-1990) through the Prism of Panpsychistic Identism, Theory in Biosciences, no. 127, pp. 297-322.

Received: April 26, 2019

Accepted: March 19, 2020

Authors' information:

Georgy S. Levit - Dr. Sci. in History of Biology, Associate Professor (Privatdozent); georgelevit@gmx.net

Uwe Hossfeld - Dr. Sci. in History of Natural Science, Dr. Sci. in Philosophy, Professor;

uwe.hossfeld@uni-jena.de

\section{Биология и панпсихизм: немецкие эволюционисты и философ Теодор Циен (1862-1950)}

\section{Г.С. Левит, У. Хоссфельд}

Йенский университет имени Фридриха Шиллера, Am Steiger 3, D-07743, Йена, Германия

Для цитирования: Levit G. S., Hossfeld U. Biology and panpsychism: German evolutionists and a philosopher Theodor Ziehen (1862-1950) // Вестник Санкт-Петербургского университета. Философия и конфликтология. 2020. Т. 36. Вып. 2. С. 240-253. https://doi.org/10.21638/spbu17.2020.203 
Теодор Циен (в отечественной литературе иногда: Циген) был известным немецким психиатром и психологом и малоизвестным философом первой половины XX в., создавшим экзотическое субъективно-идеалистическое учение на квазиэкспериментальных основаниях. Несмотря на то что современники (например, В. Ленин) считали Циена представителем того же философского направления (эмпириокритицизм), что и Мах и Авенариус, он никогда не достигал их уровня известности в философии. В то же время философия Циена оказала значительное влияние на немецкую биологию, прежде всего благодаря Бернхарду Реншу, который, в свою очередь, был наиболее значительной фигурой в немецкой эволюционной биологии как один из создателей «современного синтеза» (т.е. современного дарвинизма). Ренш не был единственным биологом, испытавшим влияние Циена. Циен находился в контакте с «немецким Дарвином» Эрнстом Геккелем и сыграл заметную роль в теоретическом корпусе основателя биологической систематики Вилли Хеннига. Каким образом можно объяснить малозаметную роль Циена в истории философии, притом что его философия оказалась востребована в биологии? Наша гипотеза заключается в том, что Циен стал заметной фигурой в истории биологии, поскольку его эпистемология оказалась хорошо совместимой с монизмом, широко распространенным в немецких естественных науках. Кроме того, репутация Циена как практикующего психиатра способствовала восприятию его философского учения как квазиэкспериментального.

Ключевые слова: Теодор Циен (Циген), идентизм, эмпириокритицизм, Эрнст Геккель, Бернхард Ренш, Вилли Хенниг, психомонизм, монизм, синтетическая теория эволюuзuи.

Статья поступила в редакцию 26 апреля 2019 г;; рекомендована в печать 19 марта 2020 г.

Контактная информация:

Левит Георгий Семёнович - д-р биол. наук, приват-доцент; georgelevit@gmx.net Уве Хоссфельд - д-р естеств. наук, д-р филос. наук, проф.; uwe.hossfeld@uni-jena.de 